Research Report No. 1/2013

\title{
Rational Choices, But for Whom? Transnational Financial Regulation after the Crisis
}

Douglas Sarro

Follow this and additional works at: http://digitalcommons.osgoode.yorku.ca/clpe

\section{Recommended Citation}

Sarro, Douglas, "Rational Choices, But for Whom? Transnational Financial Regulation after the Crisis" (2013). Comparative Research in Law \& Political Economy. Research Paper No. 1/2013.

http://digitalcommons.osgoode.yorku.ca/clpe/250 


\section{OSGOODE}

\section{OSGOODE HALL LAW SCHOOL}

Comparative Research in Law \& Political Economy

RESEARCH PAPER SERIES

Research Paper No. 1/2013

\section{Rational Choices, but for Whom? Transnational Financial Regulation after the Crisis}

Douglas Sarro

Editors:

Peer Zumbansen (Osgoode Hall Law School, Toronto, Director Comparative Research in Law and Political Economy)

John W. Cioffi (University of California at Riverside)

Leeanne Footman (Osgoode Hall Law School, Toronto, Production Editor)

Comparative Research in Law \& Political Economy 


\title{
Rational Choices, but for Whom? Transnational Financial Regulation after the Crisis
}

\author{
Douglas Sarro*
}

\begin{abstract}
A review of Chris Brummer, Soft Law and the Global Financial System: Rule Making in the 21st Century (Cambridge University Press, 2012) 312 pp, Pbk ISBN-13: 9780521181679.
\end{abstract}

The financial crisis of 2008 brought into stark relief that the decisions of a small class of financial professionals can make or break the global economy. The transnational regulatory framework in which these decisions are made, however, remains for most a haze of acronyms.

Professor Chris Brummer of Georgetown University Law Center takes a step towards clarifying this haze with Soft Law and the Global Financial System, which describes in accessible prose how international financial regulation works, how individual regulators relate to one another, and how these organisations contributed to the financial crisis. It also seeks to explain why regulators comply with international financial regulation, even though little of it enjoys legal force, and argues for the legitimacy of international financial regulation.

After (1) summarising Brummer's anatomy of international financial regulation, I engage with Brummer's account of its (2) effectiveness and (3) legitimacy.

I argue that Brummer, in relying on rational choice theory to explain why regulators create and implement soft law, overlooks other approaches that might more adequately explain these phenomena. Unlike rational choice theory, which assumes regulators' interests and preferences to be constant, these other approaches, which can be classified under the broad heading of 'constructivism,' ${ }^{1}$ hold that interests and preferences are socially constructed, and will evolve over time, in part through interaction between local and international regulators.

JD candidate, Osgoode Hall Law School, Canada.

1 One such approach is called Cognitivist Regime Theory. See James G March and Johan P Olsen, 'The Institutional Dynamics of International Political Orders' (1998) 52 International Organization 943, 968-9. Another, called Systems Theory, has been especially influential in Legal Theory. See Gunther Teubner, 'Substantive and Reflexive Elements in Modern Law' (1983) 17 Law \& Society Review 239. 
Once we accept the likelihood that the interests and preferences driving the development of financial regulation are constructed, the question that arises is who, exactly, is doing the constructing? The answer to this question-a small, technocratic elite, increasingly disconnected from the public at large ${ }^{2}-$ casts doubt on Brummer's optimistic view that financial regulation will eventually respond to the needs of a broader swath of the global public. It instead indicates that regulators will continue to pursue the same laissezfaire approach that helped to cause the financial crisis in the first place.

However, despite such cause for a more cautious reading of Brummer's account, his analysis is a most welcome and extremely astute depiction of the continuously evolving global financial architecture.

\section{HOW INTERNATIONAL FINANCIAL REGULATION WORKS}

Brummer begins by explaining why international financial regulation has become necessary. First, transactions that take place in multiple jurisdictions are subject to multiple regulators, leading to a danger that regulators in one jurisdiction will attempt to enforce regulations in a way that undermines the policy goals of regulators in other jurisdictions (40-43). Second, firms can evade local regulation altogether by carrying out transactions in jurisdictions with weak regulation. The Mexican peso and Thai Bhat crises of the 1990s illustrate how unsound regulation, even in an apparently minor economy, can fuel a regional or global financial crisis (13-14).

Brummer goes on to describe the international financial regulators as they operate today, dividing them into three groups. The first are the 'agenda-setters', the G20 and the Financial Stability Board (FSB), which set broad standards for and generally coordinate the work of other regulators. The second are the 'sectoral standard setters', which focus on a specific financial sector such as banking, in the case of the Basel Committee on Banking Supervision (BCBS), or securities, in the case of the International Organization of Securities Commissions (IOSCO). The third are the 'specialized standard setters', which work within a more narrow area such as accounting, in the case of the International Accounting Standards Board (IASB), or derivatives, in the case of the International Swaps and Derivatives Association (ISDA) (68).

The narrative of the causes of the financial crisis is a familiar one. US banks issued too many mortgages to buyers who could not reasonably be expected to pay them (what are called 'subprime mortgages'). They spread the resulting risk by repackaging these mortgages into asset-backed securities and other complex financial instruments, and selling them to people who did not know what they were buying. Once the 'teaser' rates 
attached to these mortgages began to expire, default rates soared and the value of the securities collapsed, wiping out investors and the banks that bet against their default. ${ }^{3}$

Brummer's account, however, sets itself apart by focusing exclusively on the role transnational regulation played in allowing the crisis to happen and, in some cases, making it worse. He explains these shortcomings by applying a rational choice framework centred on local regulators. Local regulators, Brummer explains, will refuse to cooperate to address a common policy issue through an international forum if doing so will render their local capital markets less competitive, or if their regulatory philosophies (what a game theorist might call preferences) dictate different solutions to the issue. ${ }^{4}$

This approach is illustrated, for example, in his treatment of the Basel capital requirements, promulgated by the BCBS. ${ }^{5}$ These requirements, though intended to reduce systemic risk in the banking system, were never applied to shadow banking institutions such as hedge funds and investment banks, even though they were the most significant source of systemic risk in the financial sector. ${ }^{6}$ No international agreement to apply the requirements could be found, Brummer explains, because US regulators had 'little interest' in broader regulation. ${ }^{7}$

Brummer also notes that regulators failed to inform themselves about credit default swaps, ${ }^{8}$ and as a result subjected them to little or no regulation (223). These instruments would eventually bring about the collapse of Lehman Brothers and the near-collapse of AIG, which used these instruments to make massive bets against the collapse of the US housing market. In addition, regulators also turned a blind eye to the credit rating agencies that gave subprime mortgage-backed securities AAA ratings. Basel, along with the IAS 39 accounting standards, made matters worse by encouraging banks to overestimate the value of their derivative assets while underestimating the risk these assets posed to their balance sheets (220-31).

3 Nouriel Roubini and Stephen Mihm, Crisis Economics: A Crash Course in the Future of Finance (Penguin, 2010) 62-85; Michael M Lewis, The Big Short: Inside the Doomsday Machine (WW Norton, 2010) 47.

4 Ibid, 130-3. This framework is explored in greater depth in Part 2 below.

5 The Basel capital requirements are intended to ensure that banks hold enough capital to withstand a substantial decline in the value of their assets, such as mortgages and sovereign debt. They require banks to maintain a minimum ratio of capital to assets; this minimum varies depending on the risk attached to their assets.

6 This is because of their size (their assets totalled US $\$ 40$ billion in 2008) and because they tended to trade in the riskiest assets. See Brummer, 220-2.

7 Brummer does not make clear whether this lack of interest was due to the ideology of US regulators or because US shadow banks stood to gain from lax regulation (222).

8 Credit default swaps allow a party to buy insurance on a debt obligation not owned by that party. The party makes regular payments to the counterparty for as long as the debt obligation continues. If the debt goes into default, however, the party receives a windfall from the counterparty. A credit default swap is in essence a bet that an underlying debt (eg subprime mortgages) will go into default. 


\section{EXPLAINING COMPLIANCE}

The problem, in short, was not one of compliance. Regulators largely complied with international financial standards as they existed prior to the crisis; the problem was that these standards were insufficient to prevent a crisis. Brummer seeks to explain why regulators choose to comply with soft law, and in so doing borrows a game theory (or rational choice) framework developed by Andrew Guzman, centred on what Guzman calls 'the three R's of compliance': reputation, reciprocity, and retaliation. ${ }^{9}$

This explanation proceeds as follows. Actors may choose to either cooperate or defect from negotiations. A decision to cooperate benefits an actor's reputation, as that actor is deemed more trustworthy by its peers. It may also encourage peers to reciprocate efforts at cooperation. Finally, a decision to cooperate minimises the risk of retaliation from peers. Actors that consistently defect, on the other hand, risk retaliation from their peers and from international institutions (140-7). Consistent monitoring of regulators' activities, Brummer says, is crucial to ensuring that defecting states cannot try to mislead their peers into believing they are cooperating (156-7).

Brummer also explains why states may disagree on proposals for new soft law, relying largely on a rational choice framework. Regulators will refuse to cooperate if adjustment costs are excessive, or where reform will render local capital markets less competitive. Brummer also argues that regulators may refuse to cooperate if their regulatory philosophies (what a game theorist might call preferences) dictate different solutions to the same problems (130-3).

Brummer's rational choice framework accomplishes the goal he sets out for it: it explains why regulators comply with existing soft law, and why they may disagree on proposals for new soft law. The approach he adopts has been endorsed by other scholars applying a law \& economics lens to public international law, ${ }^{10}$ albeit with some resistance. $^{11}$

However, that being said, Brummer's trusting reliance on rational choice theory prevents him from addressing further possible explanations for cooperation. By assuming actors' interests (and preferences) to be static, Brummer neglects the possibility that international regulators, by facilitating ongoing cooperation and communication

9 Andrew T Guzman, How International Law Works: A Rational Choice Theory (Oxford University Press, 2007) 33; see also Andrew T Guzman and Anthony Meyer, 'International Soft Law' (2011) 2 Journal of Legal Analysis 171-225, http://papers.ssrn.com/sol3/papers.cfm?abstract_id=1353444 (accessed 22 February 2012).

10 Anne van Aaken, 'Effectuating Public International Law through Market Mechanisms?' (2009) 165(1) Journal of Institutional and Theoretical Economics 33.

11 See eg Peer Zumbansen, 'The State as "Black Box" \& the Market as Regulator: A Comment on Anne Van Aaken's "Effectuating Public International Law through Market Mechanisms"” (2009) 165(1) Journal of Institutional and Theoretical Economics 62, http://papers.ssrn.com/sol3/papers.cfm?abstract_id=1292789 (accessed 17 February 2012). 
between local regulators, have helped to reconstruct these regulators' philosophies and perception of their interests. ${ }^{12}$

It is also necessary to take issue with two of the assertions he makes about other characterisations of soft law in existing literature. First, he argues that International Relations has little to say about soft law. He claims that this discipline is dominated by the realist paradigm, which held that international institutions and soft law merely reflect the existing balance of power between states and have no power in and of themselves $(4,137)$.

This view is, however, questionable. A recent survey of International Relations scholars in the United States showed that the paradigm that enjoys the broadest following among these scholars is not realism, but constructivism, a paradigm that argues that soft law can deeply influence state behaviour by reconstructing their perception of their interests. $^{13}$

Brummer also seeks to distinguish his work from the networked governance literature pioneered by Anne Marie Slaughter, noting that this school, by emphasising the benefits of cooperative rule-making by epistemic communities in the abstract, 'fails to recognize that rules have distributive implications that can ... prevent [parties] from finding any common position' (129). This criticism is convincing in part because it was recognised by Slaughter herself, who has stated that 'researchers must develop a new branch of game theory that can identify more precisely the kinds of problems for which the formation of a network is an optimal solution.' ${ }^{\prime 4}$

This is essentially the approach that Brummer has taken, borrowing from the game theory framework developed by Guzman and adding his own explanation of why states refuse to accede to new soft law norms, which itself largely relies on rational choice. Rather than repudiating network theory, Brummer builds on it.

12 Alexander Wendt, 'Anarchy is what States Make of it: The Social Construction of World Politics' (1992) 46 International Organization 391, 416-17; Helmut Willke, Smart Governance: Governing the Global Knowledge Society (Campus, 2007) 25-29. It has also been made clear, at least since the rise of Legal Realism, that the market system itself, and finance with it, must be understood to be a result of social and legal construction. See Robert Hale, 'Coercion and Distribution in a Supposedly Non-Coercive State' (1923) 38 Political Science Quarterly 470.

13 James D Long, Daniel Maliniak, Susan Peterson and Michael J Tierney, TRIP Around the World: Teaching, Research, and Policy Views of International Relations Faculty in 20 Countries (Institute for the Theory and Practice of International Relations, College of William and Mary, January 2012), http:// irtheoryandpractice.wm.edu/projects/trip/TRIP\%202011\%20RESULTS\%20US\%20RESPONDENTS.pdf (accessed 17 February 2012). Incidentally, the work Brummer cites in support of this claim, The Limits of International Law (Oxford University Press, 2006), is authored by Jack L Goldsmith and Eric A Posner, who are professors of international law, not international relations. This work by no means reflects a consensus in either international relations or international law. See Oona A Hathaway and Ariel N Lavinbuk, 'Rationalism and Revisionism in International Law' (2006) 119 Harvard Law Review 1404, 1407-15; Stacie Goddard, ‘The Limits of International Law' (2005) 120 Political Science Quarterly 710.

14 Anne Marie Slaughter and David Zaring, 'Networking Goes International: An Update' (2006) 2 Annual Review of Law \& Social Science 211, 220. 


\section{THE LEGITIMACY PROBLEM}

After developing a framework for how financial cooperation works (or does not work), Brummer shifts his attention to one of the key dimensions of global financial governance, and indeed of global governance in general: legitimacy. Domestic legislatures, he notes, have granted domestic regulators sufficient authority to represent their interests on the international stage as members of transnational regulatory bodies (209). Brummer is also optimistic that financial regulators will open up their membership to include regulators from outside Western Europe and North America, pointing to the emergence of the G20 as the leading financial agenda setter and the recent expansion of the membership of key standard setters like the BCBS $(189,194,209)$.

But formal accountability to a legislature may not be enough to ensure that financial regulation is carried out in a way that protects the interests of individuals outside the financial profession. The securities regulators and central banks that were members of IOSCO and the BCBS, respectively, were formally accountable to legislatures before the crisis. Yet the regulations they imposed appear to have served the short-term interests of the financial sector better than they have the long-term interests of the public at large (220-32).

Brummer aptly notes that financial regulation is a prime candidate for regulatory capture (185). Finance is a highly complex field, mastered only by a small class of people. As a result, if one accepts that the interests and preferences of states and regulators are constructed, one can conclude that this class plays an influential role in constructing these interests and preferences. This class has an incentive to construct interests and preferences in a way that favours laissez-faire regulation, as indeed many of them have for the last two to three decades. This class, or at least the segment of it employed in the financial sector, ${ }^{15}$ enjoy the benefits of lax financial regulation, reaped in the form of enormous bonuses prior to the crash, while its costs are distributed across a broad spectrum of people who lack the expertise to scrutinise the regulators' actions. ${ }^{16}$

The international regulatory response to the financial crisis has followed almost to a beat the pattern followed by captured regulators after being exposed to scrutiny in the wake of a crisis. ${ }^{17}$ Enhanced public scrutiny leads to demands for an immediate regulatory response. This response, however, is crafted by the same experts who failed to prevent the crisis in the first place, as they are the only individuals with the technical

15 There has been much mention in the United States of the 'revolving door' between financial regulators and the financial industry. See Timothy A Canova, 'Financial Market Failure as a Crisis in the Rule of Law: From Market Fundamentalism to a New Keynesian Regulatory Model' (2009) 3 Harvard Law \& Policy Review $369,384-9$.

16 Walter Mattli and Ngaire Woods, 'In Whose Benefit? Explaining Regulatory Change in Global Politics' in Walter Mattli and Ngaire Woods (eds), The Politics of Global Regulation (Princeton University Press, 2009) $1,10-11$.

17 Ibid, 26-27. 
expertise to craft this response. ${ }^{18}$ After a brief period of reform, public interest abates and the regulator reassumes its old habits. ${ }^{19}$

It is not clear how expanding the membership of international financial institutions will address this problem. On the contrary, the inclusion of representatives from emerging market regulators may mean only that transnational financial institutions will represent a broader spectrum of the financial class.

The legitimacy of international financial regulation is thus intertwined with a more general concern, which has become especially salient over the past few months with the rise of Occupy Wall Street. ${ }^{20}$ This concern is that there is emerging a global class of elites, connected with each other as a result of having been educated at the same top-ranked universities and having worked at the same circle of top-flight firms, but increasingly disconnected from ordinary people. ${ }^{21}$ This elite takes what appears to be a controlling role in defining the interests and preferences of their states and international organisation; though members of this elite may aspire to be acting in the public interest, their isolation from the broader public hinders their ability to see what the public interest might be.

This concern, it should be noted, long predates Occupy Wall Street, and has been raised by authors at both ends of the political spectrum. Samuel Huntington lamented the rise of 'Davos Man', who 'inhabit[s] a "socio-cultural bubble" apart from the cultures of individual nations."22 This 'superclass,, ${ }^{23}$ as David Rothkopf calls it, inhabits what John Micklethwait and Adrian Wooldridge of the Economist call 'a world within a world, linked to each other by myriad global networks but insulated from more hidebound members of their own societies. ${ }^{24}$

The problems of regulatory capture, and a decoupling of financial elites from the people whose lives are affected by the rules they make, are given only passing treatment

18 US President Barack Obama has been said to have been beholden to his economic and financial experts. See Ron Suskind, Confidence Men: Wall Street, Washington, and the Education of a President (HarperCollins, 2011). Cf Ezra Klein, 'Obama's Flunking Economy: The Real Cause' New York Review of Books (24 November 2011), www.nybooks.com/articles/archives/2011/nov/24/obamas-flunking-economy-real-cau se/?pagination=false (accessed 17 February 2012).

19 Mattli and Woods (n 16) 27.

20 See Michael Greenberg, 'What Future for Occupy Wall Street?' New York Review of Books (9 February 2012), www.nybooks.com/articles/archives/2012/feb/09/what-future-occupy-wall-street/?pagination=false (accessed 22 February 2012).

21 See eg Willke (n 12) 36-37; David Ignatius, 'Davos and Disconnected Elites' Washington Post, 27 January 2012 , www.washingtonpost.com/opinions/davos-and-disconnected-elites/2012/01/27/gIQA5AKPWQ_story. html (accessed 17 February 2012).

22 Samuel P Huntington, 'Dead Souls: The Denationalization of the American Elite' (2004) 75(1) The National Interest 5,7 .

23 David Rothkopf, Superclass: The Global Power Elite and the World they are Making (Farrar, Straus and Giroux, 2008).

24 John Micklethwait and Adrian Wooldridge, A Future Perfect: The Challenge and Hidden Promise of Globalization (Crown Business, 2000) 241-2. 
by Brummer (185). It would seem that closer consideration of these issues would be necessary before drawing any conclusions about the legitimacy of transnational financial regulators.

\section{CONCLUSION}

Brummer performs an immensely valuable service by demystifying the world of financial regulation for the non-specialist reader. He also offers an accessible account of the role played by transnational regulators both in the prelude to and the aftermath of the financial crisis. Furthermore, Brummer expands on the 'global networks' literature by explaining why networks can resolve some regulatory problems but not others. While this explanation would have been even stronger had Brummer accounted for the way in which institutions help to reconstruct the interests and identities of their members, it remains a forceful rebuke to those who dismiss soft law as irrelevant. ${ }^{25}$ In short, Soft Law is a timely intervention on a topic that deserves more attention from legal scholars. 